\title{
GETTING AWAY WITH MURDER: SEGREGATION AND VIOLENT GRIME IN URBAN AMERICA
}

\section{DOUGLAS S. MASSEY†}

\section{INTRODUCTION}

Although rates of violent crime and crime victimization are going down for most groups in the United States, ${ }^{1}$ they are rising for African-Americans. ${ }^{2}$ A variety of theories have been put forth to explain this trend, but none have come to terms with black segregation. In this Article, I develop a theory that links high rates of black crime to two features of U.S. urban society: high rates of black poverty and high levels of black segregation. The coincidence of these two conditions yields an ecological niche within which rates of crime, levels of violence, and risks of victimization are high. In adapting to these conditions, people rationally adopt individual and collective strategies that offer some protection, but also fuel the violence and give it a self-perpetuating character. Unless desegregation occurs, this cycle of violence is likely to continue; however, the perpetuation of violence paradoxically makes desegregation less likely by increasing the benefits to whites of black residential isolation.

Part I of this Article provides a brief overview of the nature and prevalence of crime in the United States and its relationship to segregation. Part II shows that two conditions known to exist within urban America-high levels of black segregation and high rates of black poverty-interact to create a unique ecological niche for black Americans, within which violent behavior becomes a logical, rational adaptation. Part III reviews recent ethnographic research on racially isolated, crime-ridden areas to show how residents adapt to this structurally produced environment. Part IV attempts to explain why it has been so difficult to implement policies to promote desegregation, pointing out the economic and political benefits that whites derive from residential segregation. Part $V$ concludes with suggestions of alternative scenarios for the future of urban America.

+ Dorothy Swaine Thomas Professor of Sociology, University of Pennsylvania; Ph.D. 1978, Princeton University.

${ }^{1}$ See David Zucchino, Today's Violent Crime Is Old Story with a Twist, PHILA. INQUIRER, Oct. 30, 1994, at A1, A22 (noting that crime victimization rates are at their lowest levels in 20 years).

${ }^{2}$ See id. (noting that African-Americans are the only group whose rates remain "disproportionately high"). 


\section{CRIMe AND Segregation IN THE UNITEd States}

Americans believe they are living through an unprecedented boom in violent crime. ${ }^{3}$ They are wrong. Serious crimes reported to the police actually dropped by $3 \%$ during each of the past two years, ${ }^{4}$ and from 1980 to 1992 the murder rate fell by $9 \% .^{5}$ These declines cannot be attributed to the underreporting of crimes to the police, because a similar shift is evident in a nationwide victimization survey carried out by the Bureau of Justice Statistics of the National Institute of Justice. ${ }^{6}$ According to this survey, criminal victimization rates are at their lowest levels in two decades: the reported incidence of aggravated assault and robbery dropped by $11 \%$ between 1973 and $1992,{ }^{7}$ while the victimization rate for rape fell by $28 \%^{8}$ and that for burglary fell by $47 \% .^{9}$ Over roughly the same period, the percentage of households experiencing crime fell substantially, from $32 \%$ to $23 \% .^{10}$

One would never guess that crime rates were on the wane by watching television, however. ${ }^{11}$ News coverage of violent crime by the three major networks doubled from 1992 to 1993, while coverage of murders tripled. ${ }^{12}$ In addition, a spate of new "realitybased" cop shows, rescue programs, and tabloid offerings has given crime extensive airplay after the nightly news. ${ }^{13}$ Thus, despite constant or declining crime rates in the United States, Americans are exposed, albeit vicariously, to more crime and violence than ever before, and consequently they feel more vulnerable and threatened. These feelings are exacerbated by two very real shifts in the nature of crime in the United States. Although rates of crime are going down, those crimes that are committed are more likely to involve guns, ${ }^{14}$ and they are more likely to be committed by chil-

${ }^{3}$ See id. (discussing the common belief that these rates are skyrocketing).

${ }^{4}$ See id. at A22, A23 (citing FBI statistics from 1992 and 1993).

${ }^{5}$ See id. at A22 (noting that the country's peak homicide rates for the century came not recently, but in 1931-34 and 1979-81).

${ }^{6} \mathrm{Cf}$. id. (noting that victimization surveys are a better gauge of crime than police reports).

${ }^{7}$ See $i d$. (noting that ${ }^{\text {just one in }} \mathbf{2 0}$ robberies results in serious injury and lost property").

${ }^{8}$ See id.

${ }^{9}$ See id.

${ }^{10}$ See id. (comparing 1975 to 1992).

${ }^{11}$ See id. (arguing that television contributes to "overheated perceptions of violence").

${ }^{12}$ See id. (citing a Center for Media and Public Affairs survey).

${ }^{13}$ See id.

${ }^{14}$ See id. at Al (noting that more crime victims are being killed primarily because 
dren. ${ }^{15}$ Crime now seems more "senseless" because deadly acts are carried out by people too young to realize the implications of their decisions. Altercations that twenty years ago would have ended in a fistfight and a bloody nose now terminate with a corpse riddled by twenty-two caliber bullets fired from an automatic machine pistol.

In addition to the rise in coverage of violent crime, the increasing use of lethal weapons, and the growing involvement of children in criminal activity, there is one more fact about contemporary crime that increases its visibility and resonates strongly in the American psyche: race. Although rates of crime may be going down for the United States generally, they are spiraling upward for one specific group of Americans: those of African origin. ${ }^{16}$

According to a 1992 National Institute of Justice survey, blacks are now more likely to become victims of violence than at any point during the last two decades. ${ }^{17}$ Black teenagers are eleven times more likely to be shot to death and nine times more likely to be murdered than their white counterparts. ${ }^{18}$ Among black males, in particular, homicide rates have skyrocketed. Whereas young black American males were killed at the rate of about forty-five per 100,000 in 1960 , by 1990 the rate was 140 per 100,000, compared to a figure of approximately twenty per 100,000 for young white males (still the highest rate in the industrialized world). ${ }^{19}$ This alarming trend has prompted some observers to dub young black men "an endangered species." 20

Thus, when television viewers (who are mostly white) see rising criminal violence on television, the people they see committing increasingly lethal crimes are predominantly young, male, and black. This carries profound and disturbing consequences for American race relations. Although virtually all the victims of black criminals are also black, ${ }^{21}$ television viewers still learn to fear young black men. As a result, calls for harsher sentences, more police, and tougher treatment inevitably carry strong racial overtones, because

of increased gun use).

${ }^{15}$ See id. (noting that "both killers and victims are younger than ever").

${ }^{16}$ See supra note 2 and accompanying text.

${ }^{17}$ See Zucchino, supra note 1, at A23.

${ }^{18}$ See id.

${ }^{19}$ See id. at A22.

${ }^{20}$ Deborah Pothrow-Stith \& Michaele Weissman, Deadly ConSequences 64 (1991).

${ }^{21}$ See, e.g., Understanding and PReventing Violence 77 (Albert J. Reiss, Jr. \& Jeffrey A. Roth eds., 1993) ( $[$ [B]lacks assault blacks at about 800 percent of the chance-encounter rate."). 
such measures will be directed predominantly at black males.

A variety of theories have been put forth to explain the new wave of violent crime in black America. Some observers have attributed black violence to the unique set of stresses experienced by urban black communities. ${ }^{22}$ Others have linked it to persistent racial inequality, which has produced frustration expressed as violence. ${ }^{23}$ Others argue that black crime is a natural consequence of prolonged poverty, joblessness, and income deprivation. ${ }^{24}$ Still others hold that it stems from a distinctive subculture that accepts and condones high levels of violence. ${ }^{25}$ Richard Herrnstein and Charles Murray have gone so far as to imply that black criminality stems from the lower intelligence of African-Americans. ${ }^{26}$

Missing from all of these explanations, however, is any serious attempt to come to terms with the most salient and far-reaching fact about black America: its high degree of residential segregation. Simply put, African-Americans are unique: they are and have always been more segregated than any other racial or ethnic group in the United States. ${ }^{27}$ Blacks are segregated so highly, and on so many

22 See Harold M. Rose \& Paula D. McClain, Race, Place, and Risk: Black HOMICIDE IN URBAN AMERICA 62-66 (1990) (discussing the effect of "elements of strain" and "stressors" on various neighborhoods).

${ }^{23}$ See generally Judith R. Blau \& Peter M. Blau, The Cost of Inequality: Metropolitan Structure and Violent Crime, 47 AM. Soc. REV. 114 (1982) (arguing that high crime rates are caused by racial and economic inequalities); Peter M. Blau \& Reid M. Golden, Metropolitan Structure and Criminal Violence, 27 Soc. Q. 15 (1986) (same); Robert J. Sampson, Effects of Inequality, Heterogeneity, and Urbanization on Intergroup Victimization, 67 Soc. ScI. Q. 751 (1986) (same).

${ }^{24}$ See generally William C. Bailey, Poverty, Inequality, and City Homicide Rates, 22 CRIMINOLOGY 531 (1984) (linking black crime to economic deprivation); Colin Loftin \& Robert N. Parker, An Errors-in-Variable Model of the Effect of Poverty on Urban Homicide Rates, 23 CRImiNOLOGy 269 (1985) (same); Robert J. Sampson, Race and Criminal Violence: A Demographically Disaggregated Analysis of Urban Homicide, 31 CRIME \& DELINQ. 47 (1985) (same); Kirk R. Williams, Economic Sources of Homicide: Reestimating the Effects of Poverty and Inequality, 49 AM. SOC. REV. 283 (1984) (same); Kirk R. Williams \& Robert L. Flewelling, The Social Production of Criminal Homicide: A Comparative Siudy of Disaggregated Rates in American Cities, 53 AM. Soc. REV. 421 (1988) (same).

${ }^{25}$ See, e.g., LyNn A. Curtis, Violence, Race, and Culture 23-42 (1975) (analyzing the violent subculture of blacks).

${ }^{26}$ See Richard J. HerRnStein \& Charles MURRAY, THe Bell CuRve: INTElliGENCE AND CLASS STRUCTURE IN AMERICAN LIFE 338-39 (1994) (noting that the large difference between black and white crime rates is drastically reduced when $I Q$ is taken into account).

${ }^{27}$ See Douglas S. Massey \& Nancy A. DENTON, American Apartheid: SEgrecation AND THE MAKING OF THE UNDERclass 2 (1993) ("No group in the history of the United States has ever experienced the sustained high level of residential segregation that has been imposed on blacks in large American cities . ..."). 
geographic dimensions simultaneously, that Nancy Denton and I coined the term "hypersegregation" to describe their situation. ${ }^{28}$ According to the 1990 Census, blacks in twenty metropolitan areas, containing nearly forty percent of the African-American population, live under conditions of hypersegregation. ${ }^{29}$

This unusual degree of segregation is largely involuntary and stems from the operation of three interrelated and mutually reinforcing forces in American society: high levels of institutionalized discrimination in the real estate and banking industries; ${ }^{30}$ high levels of prejudice among whites against blacks as potential neighbors; ${ }^{31}$ and discriminatory public policies implemented by whites at all levels of government. ${ }^{32}$ Racial segregation is not simply a historical legacy of past prejudice and discrimination. On the contrary, it is actively perpetuated by institutional actions, private behaviors, and public policies that continue to the present day. ${ }^{33}$

A growing body of research has examined the deleterious consequences of segregation for the black community, linking it to high rates of joblessness, unwed parenthood, welfare dependency, infant mortality, and poverty. ${ }^{34}$ With two exceptions, however, neither

${ }^{28}$ Douglas S. Massey \& Nancy A. Denton, Hypersegregation in U.S. Metropolitan Areas: Black and Hispanic Segregation Along Five Dimensions, 26 DEMOGRAPHY 373, 373 (1989).

${ }^{29}$ See Nancy A. Denton, Are African Americans Still Hypersegregated?, in RESIDENTIAL APARTHEID: THE AMERIGAN LeGaCY 49, 63 (Robert D. Bullard et al. eds., 1994) (stating that in 1990 there were 20 hypersegregated metropolitan areas in the United States); Douglas S. Massey, The Residential Segregation of Blacks, Hispanics, and Asians: 1970 to 1990, in IMmIGRATION AND THE CHANGING STATUS OF RACE RELATIONS (Gerald D. Jaynes ed., forthcoming 1995) (noting that the black population of these hypersegregated metropolitan areas constitutes nearly $40 \%$ of the total black population in the United States).

${ }^{30}$ See JOHN Yinger, Closed DoOrs, LOST OpPortunities: The Causes, CONSEQUENCES AND CURES FOR RACIAL AND ETHNIC DISCRIMINATION IN HOUSINC (forthcoming 1995) (discussing evidence of real estate and banking discrimination).

${ }^{31}$ See id. (describing discrimination in housing market transactions); Reynolds Farley et al., Stereotypes and Segregation: Neighborhoods in the Detroit Area, 100 AM. J. Soc. 750, 753 (1994) (analyzing housing patterns in the Detroit area).

${ }^{32}$ See MASSEY \& DENTON, supra note 27, at 186-216 (noting the continuance of segregation due to discriminatory public policies).

${ }^{33}$ See George Galster, Racial Discrimination in Housing Markets During the 1980s: A Review of the Audit Evidence, 9 J. PLAN. EDUC. \& RES. 165, 172 (1990) (noting that racial discrimination was still a dominant feature of metropolitan housing markets in the 1980s); George Galster, Racial Steering by Real Estate Agents: Mechanisms and Motives, 57 Soc. RES. 39, 59 (1990) (discussing how real estate firms steer clients to neighborhoods of predominately the same race); George Galster, Racial Steering in Urban Housing Markets: A Review of the Audit Evidence, 18 REV. BLACK POL. ECON. 105, 124 (1990) (same).

${ }^{34}$ See MASSEY \& DENTON, supra note 27, at 13; YINGER, supra note 30 (discussing 
theorists nor researchers have sought to link racial segregation to the cycle of violent crime now overtaking inner cities, ${ }^{35}$ but when the link has been examined, it has proven to be quite strong.

John Logan and Steven Messner studied the connection between segregation and crime using a sample of suburbs surrounding fiftyfour metropolitan areas. ${ }^{36}$ They measured the degree of segregation between blacks and whites across municipalities within suburban rings and related it to the rate of suburban crime, while statistically controlling for other factors such as poverty, population mobility, the minority percentage, age composition, and population size. ${ }^{37}$ They found that racial segregation was very strongly associated with rates of violent crime in both 1970 and $1980 . .^{38}$ According to their results, the more racially segregated a suburban ring was, the higher its rate of violent crime. ${ }^{39}$

Although Logan and Messner found a clear, positive relationship between segregation and criminal violence, the level of black-white segregation was not the strongest predictor in their statistical model; ${ }^{40}$ other factors, such as poverty and income inequality appeared to carry more explanatory weight. ${ }^{41}$ The investigators, however, did not examine the effect of racial segregation on black crime rates. They only examined the relationship between racial segregation and overall rates of crime in suburban rings. Because

how segregation affects education and employment); George C. Galster \& Sean P. Killen, The Geography of Metropolitan Opportunity: A Reconnaissance and Conceptual Framework 18-21 (May 4, 1994) (paper presented at the Fannie Mae Annual Housing Conference) (discussing how segregation affects childhood development, fertility, mortality, labor market outcomes, and crime).

35 See generally John R. Logan \& Steven F. Messner, Racial Residential Segregation and Suburban Violent Crime, 68 SoC. SCI. Q. 510 (1987) (arguing for the "consider[ation of] racial residential segregation as an independent variable with important consequences for metropolitan communities"); Ruth D. Peterson \& Lauren J. Krivo, Racial Segregation and Black Urban Homicide, 71 Soc. FORCES 1001 (1993) (suggesting that "social isolation . . . is the mechanism by which segregation leads to higher levels of homicide among African Americans").

${ }^{36}$ See Logan \& Messner, supra note 35, at 516 (defining "[t]he units of analysis" for the study as the "suburban rings of 54 metropolitan areas.").

${ }^{37}$ See id. at 514-15 (describing the model and explaining how certain factors must be considered to assess accurately the effect of racial segregation on violent crime).

${ }^{\text {ss }}$ See id. at 523 (stating that "[w]e find, as expected, that racial residential segregation is positively associated with suburban violent crime").

${ }^{39}$ See id. at 518-23 (presenting tables with explanations describing regression analysis results).

${ }^{40}$ See id. at 523 (concluding that "racial segregation, while not the strongest determinant of violent crime, is nevertheless an important factor").

${ }^{41}$ See id. at 522 (arguing that the poverty-inequality index "is in fact the best predictor of homicide, robbery, assault, and the crime index"). 
blacks constitute only a small fraction of most suburban populations, the crimes they commit would be unlikely to have a large effect on overall rates, even if segregation were strongly related to the incidence of black crime.

In order to circumvent this problem, Ruth Peterson and Lauren Krivo studied the relationship between black segregation and black homicide in 125 central cities. ${ }^{42}$ They found that black-white segregation was by far the most important variable in explaining intercity variation in the black murder rate, dwarfing the effect of control factors such as income inequality, poverty, education, occupation, age composition, population size, and region. ${ }^{43}$ Standardized coefficients showed that the effect of segregation was 2.5 times that of the next closest factor in their statistical model. ${ }^{44}$

Peterson and Krivo differentiated between family member homicides, acquaintance killings, and homicides involving strangers. $^{45}$ They found that segregation was unrelated to homicide within families but that it did have an effect on homicides involving acquaintances and strangers. ${ }^{46}$ In other words, whatever segregation was doing to influence rates of homicide in urban black communities, the causal processes operated largely outside the home and within the public sphere.

The Peterson-Krivo study provides strong prima facie evidence of a direct link between high levels of segregation and high rates of violent crime within black America. Nonetheless, social scientists have paid scant attention to segregation as a possible explanatory factor in accounting for the recent wave of criminal violence in inner cities. ${ }^{47}$ The purposes of this Article are to explain in theoretical terms the link between segregation and violent crime and to show logically how high levels of racial segregation in U.S.

12 See Peterson \& Krivo, supra note 35, at 1006 (describing the study data and methodology).

${ }^{43}$ See id. at 1013 (stating that "[i]t is particularly striking that segregation has more influence than measures ... of some of the most central theoretical constructs ... in discussion of crime").

4t See id. at 1014 (providing table describing regression analysis of black homicide rates on segregation).

${ }^{45}$ See id. (showing how each type of homicide is influenced by various structural factors).

${ }^{46}$ See id. at 1017 (describing possible explanations of why segregation has no effect on rates of family homicides).

${ }^{17}$ See id. at 1018 (explaining that the tendency to focus on economic deprivation in past research limits understanding of the relationship between inequality and violence). 
metropolitan areas help bring about a distinctive pattern of violence within urban black communities.

\section{Creating the Niche of Violence}

High rates of crime are structurally built into the experience of urban blacks by virtue of their residential segregation because, during periods of economic dislocation, segregation concentrates poverty and anything associated with it. ${ }^{48}$ Because crime and violence are strongly correlated with income deprivation, ${ }^{49}$ any social process that concentrates poverty also concentrates crime and violence to create an ecological niche characterized by a high risk of physical injury, violent death, and criminal victimization. ${ }^{50}$

In a racially segregated city, any increase in black poverty is necessarily confined to a small number of geographically isolated and racially homogeneous neighborhoods. During times of recession, therefore, viable and economically stable black neighborhoods are transformed into areas of intense socioeconomic deprivation, where joblessness, welfare dependency, and single parenthood become the norm and where crime and social disorder are inextricably woven into the fabric of daily life. ${ }^{51}$ The coincidence of rising poverty and high levels of segregation guarantees that low-income blacks will be exposed to a social and economic environment that is much harsher than anything experienced by whites.

Scientists customarily demonstrate the effect of one variable on another by carrying out an experiment. In a controlled experiment, all factors except the one under investigation are held constant, and the investigator then manipulates the one to observe its effect on some outcome of interest. Social scientists cannot, of course, conduct experiments in the social world. They cannot randomly assign blacks to live in segregated and integrated urban cities, raise

${ }^{48}$ See Douglas S. Massey, American Apartheid: Segregation and the Making of the Underclass, 96 AM. J. Soc. 329, 337 (1990) (stating that "[i]f racial segregation concentrates poverty in space, it also focuses and exacerbates any change in the economic status of minority groups").

${ }^{19} \mathrm{See}$ id. at 342 (noting that "poverty is not a neutral variable, of course, and with high rates of poverty come a variety of other social and economic conditions ... [including] elevated crime rates").

${ }^{50}$ See id. at 347 (presenting data associating "the imposition of racial segregation" on already impoverished communities with increasing rates of crime and violence).

${ }^{51} \mathrm{See}$ id. at 351 (explaining how shifts in poverty dramatically transform lowincome black communities). 
the rate of black poverty, and then observe what happens to the geographic concentration of poverty.

They can, however, carry out the equivalent of a laboratory experiment by defining hypothetical cities, giving them constant characteristics that correspond to those in the real world, and then varying the level of racial segregation and black poverty to observe what happens to the geographic concentration of poverty. In prior work, I have carried out just such an exercise, the results of which are summarized in Table $\mathrm{I}^{52}$

\section{TABLE $I^{53}$}

EFFECT OF Rising BLACK-WHITE SEgREGATION AND RISING RATES OF BLACK POVERTY ON THE GEOGRAPHIC CONCENTRATION OF POVERTY AND GRIME IN BLACK NEIGHBORHOODS

For Typical Poor Black Person:

$\begin{array}{ll}\text { Neigh- } & \text { Neigh- } \\ \text { borhood } & \text { borhood } \\ \text { Poverty } & \text { Crime } \\ \text { Rate } & \text { Rate }\end{array}$

WITHOUT CLASS SEGREGATION

Racially Integrated City

Black Poverty Rate 20\%

$12.5 \% \quad 47.9 \%$

Black Poverty Rate $30 \%$

15.0

49.9

Racially Segregated City

Black Poverty Rate $20 \%$

20.0

52.4

Black Poverty Rate $30 \%$

30.0

60.4

WITH CLASS SEGREGATION

Racially Integrated City

Black Poverty Rate 20\%

$25.0 \quad 57.8$

Black Poverty Rate $30 \%$

30.0

61.8

Racially Segregated City

Black Poverty Rate 20\%

40.0

68.3

Black Poverty Rate $30 \%$

$60.0 \quad 84.2$

${ }^{52}$ See id. at 338.

${ }^{53}$ See Massey, supra note 48, at 338-39, 348 (providing source of data for Table I). 
To carry out the experiment, I began with an ideal city of 96,000 whites, 32,000 blacks, and sixteen neighborhoods of 8000 residents each, yielding a total city population with 128,000 inhabitants and a black percentage of $25 \% .{ }^{54}$ Blacks were initially assumed to have a poverty rate of $20 \%$, compared to a $10 \%$ rate for whites. ${ }^{55}$ I then raised the black poverty rate to $30 \%$, while keeping the white rate constant, to replicate trends that actually occurred in large American cities during the 1970 s and 1980 s, particularly in cities in the Northeast and Midwest. ${ }^{56}$ The experiment examines what happens to the geographic concentration of poverty when this shift in black poverty occurs under different conditions of class and racial segregation. Concentrated poverty occurs when poor people live in very poor places. ${ }^{57}$

The figures in the first column show how poverty is concentrated geographically whenever the overall rate of poverty increases in a racially segregated group. The top panel illustrates what would happen if no class segregation existed among blacks (that is, if poor and nonpoor blacks were to display no propensity to live in different neighborhoods). This is the simplest case and it displays in the most straightforward fashion the mechanism by which segregation concentrates poverty, thus I consider it first.

Under conditions of racial integration, the neighborhood poverty rate experienced by the average black citizen rises from $12.5 \%$ to $15 \%$ as a result of the shift in black poverty rates from $20 \%$ to $30 \% .^{58}$ That is, after the increase in black poverty, the average

54 See id. at 331.

${ }^{55}$ See id.

${ }^{56}$ See Douglas S. Massey \& Mitchell L. Eggers, The Ecology of Inequality: Minorities and the Concentration of Poverty, 1970-1980, 95 AM. J. Soc. 1153, 1185 ("The economic instability of the 1970 s most profoundly affected the fortunes of blacks. Outside of the West, particularly in the Northeast and Midwest, the 1970s brought a sharp bifurcation of black income distributions, with marked declines in the middle classes and proportionate increases among the affluent and the poor."); see also Alan J. Abramson \& Mitchell S. Tobin, The Changing Geography of Metropolitan Opportunity: The Segregation of the Poor in U.S. Metropolitan Areas, 1970 to 1990, at 6-7 (May 4, 1994) (paper presented at the Fannie Mae Annual Housing Conference) (noting one researcher's finding that "ghetto poverty increas[ed] among blacks in metropolitan areas in the $\left.1980 \mathrm{~s}^{\prime}\right)$.

${ }^{57}$ In the original experiment, I performed the simulation using two levels of class segregation (no segregation by income and high segregation by income) and four levels of racial segregation (complete integration, low segregation, high segregation, and complete segregation). For simplicity, Table I reports the extreme cases of low and high class segregation, and no and complete racial segregation. For a more complete discussion, see Massey, supra note 48, at 331-37.

${ }^{38}$ See id. at 340 (explaining the effect of rate shift on an integrated neighborhood). 
poor African-American lives in a neighborhood where $15 \%$ of the people are poor. Although the black poverty rate itself has gone from $20 \%$ to $30 \%$, in an integrated city only $25 \%$ of the inhabitants of each neighborhood are black, while the remaining $75 \%$ are white; therefore, the effect of rising black poverty is buffered by the presence of a large number of whites who are not poor. The increase in black poverty is spread widely among many integrated neighborhoods, and in each place the overall increase in poverty is muted because most residents are whites whose poverty rate did not rise. After the period of economic dislocation, therefore, the rate of neighborhood poverty experienced by blacks in a racially integrated city is only slightly higher than it was before. ${ }^{59}$

Under conditions of racial segregation, in contrast, the increase in black poverty is not spread evenly around the city, and there are no whites within neighborhoods where blacks live to buffer the effect of rising black poverty. ${ }^{60}$ The entire increase in black poverty is absorbed by a small number of all-black neighborhoods that are clustered together and spatially isolated from the rest of the city. ${ }^{61}$ As a result, when the overall rate of black poverty rises from $20 \%$ to $30 \%$, the rate of poverty experienced by poor blacks in their neighborhoods must likewise go from $20 \%$ to $30 \% .^{62}$ When all blacks are confined to $100 \%$ black neighborhoods, any increase in black poverty necessarily yields a sharp increase in the geographic concentration of poverty: no other outcome is possible. ${ }^{63}$

The foregoing results illustrate clearly the underlying mechanism by which rising segregation and increasing poverty interact to produce an increase in the geographic concentration of poverty. Moving from racial integration and a black poverty rate of $20 \%$ to racial segregation and a black poverty rate of $30 \%$ yields a sharp increase (from $12.5 \%$ to $30 \%$ ) in the level of poverty that poor blacks are exposed to in the neighborhoods where they live.

Although the foregoing results are clear, the simulation is

${ }^{59}$ See id. (explaining how a rise in the poverty rates has a less noticeable effect on the neighborhood environment when a neighborhood is racially integrated).

${ }^{60}$ See id. (arguing that as the level of segregation increases, shifts in black poverty rates are confined to black neighborhoods resulting in poverty concentration).

${ }^{61}$ See id. (showing the disparity in the effects of shifts in poverty rates on black neighborhoods).

${ }^{62}$ See id. (showing how in a completely segregated neighborhood, the shift in poverty rates causes a dramatic increase in the poverty concentration level).

${ }^{63}$ See id. ("When the two groups are completely segregated, of course, all of the increase in black poverty is absorbed by black neighborhoods."). 
unrealistic in the sense that no class segregation is assumed. In reality, of course, poor and nonpoor blacks display a tendency to live apart from one another. ${ }^{64}$ Although incorporating class segregation into the simulation makes the mathematics somewhat more complicated, the basic principle is the same: racial segregation still concentrates poor blacks within a small number of neighborhoods and raises the rate of poverty to which they are exposed, only now poor black neighborhoods bear the brunt of the increase in black poverty. ${ }^{65}$

The addition of class segregation to the simulation exacerbates the degree of poverty concentration that is imposed on poor blacks because of racial segregation. ${ }^{66}$ Given class segregation and a black poverty rate of $20 \%$, the typical poor black resident lives in a neighborhood that is $25 \%$ poor if the city is not segregated by race; but the neighborhood poverty rate becomes $40 \%$ poor if racial segregation is also imposed. ${ }^{67}$ When the overall rate of black poverty is increased to $30 \%$, the neighborhood poverty rate experienced by poor blacks jumps to $60 \%$ under conditions of racial segregation. ${ }^{68}$ In a city segregated by race as well as class, therefore, an increase in black poverty will constrain poor blacks to live in a social world where most of their friends and neighbors are also poor.

In short, rising black poverty and racial segregation interact to produce a sharp increase in the geographic concentration of poverty. Under general conditions of class segregation, moving from a city with no racial segregation and a black poverty rate of $20 \%$ to complete racial segregation and a black poverty rate of $30 \%$ means the difference between a residential environment where the vast majority of people are not poor (a neighborhood poverty rate of $25 \%$ ) to one where a large majority of people live below the poverty line (a neighborhood poverty rate of $60 \%$ ). ${ }^{69}$ All other

${ }^{6+}$ See Douglas S. Massey \& Mitchell L. Eggers, The Spatial Concentration of Affluence EN Poverty During the 1970s, 29 URB. AFF. Q. 299, 305 (1993) (showing residential segregation by income in the thirty largest metropolitan areas in the United States).

${ }^{65}$ See Massey, supra note 48, at 341 (stating that "under conditions of complete racial segregation, a $50 \%$ rise in the black poverty rate translates directly into a $50 \%$ increase in the concentration of poverty in poor black neighborhoods").

${ }^{66}$ See id.

${ }^{67}$ See id.

${ }^{68}$ See id.

${ }^{69}$ See id. 
conditions are held constant, so the difference is entirely due to the increase in black poverty and racial segregation.

As poverty is concentrated, of course, all things associated with it are concentrated, including crime. In an earlier work, I used data from Philadelphia to estimate the empirical relationship between neighborhood poverty rates and major crime rates, controlling for racial composition. ${ }^{70}$ Major crimes include murder, rape, aggravated assault, robbery, burglary, larceny, and auto theft. Using least squares regression, I estimated the relationship between crime and poverty to be: Major Crime Rate $=36.55+.02$ (percentage white) +.79 (poverty rate), where the units are census tracts and crime rates are expressed per 1000 inhabitants. ${ }^{71}$

This formula was applied to predict the crime rate associated with each neighborhood poverty level generated by our simulation. The predicted crime rates are shown in the right-hand column of Table I. Although I show predictions for scenarios with and without class segregation, I focus on the realistic case of a class-segregated city and consider what happens to neighborhood crime rates when black poverty rises under varying conditions of racial segregation.

In the absence of racial segregation, the level of crime to which poor blacks are exposed in a class-segregated city increases modestly from $57.8 \%$ to $61.8 \%$ as a result of the increase in overall black poverty, ${ }^{72}$ a small rise that would probably not be noticed by most inhabitants of the neighborhood. When the same increase in black poverty occurs under conditions of racial segregation, however, the neighborhood crime rate increases rather dramatically from $68.3 \%$ to $84.2 \%{ }^{73}$ The difference between these extremes-a neighborhood crime rate of $57.8 \%$ and a neighborhood crime rate of $84.2 \%$-is the difference between a city with no racial segregation and a black poverty rate of $20 \%$ and a city with complete racial segregation and a poverty rate of $30 \%$. Everything else, including class segregation, has been held constant.

This dramatic $45 \%$ difference in the concentration of crime stems entirely from the interaction of segregation and rising poverty, yielding two social environments that are diametrically opposed to one another. With a crime rate of $57.8 \%$, the likelihood that a person will be victimized over a ten-year period is about .45 ;

\footnotetext{
${ }^{70}$ See id. at 347.

${ }^{71} \mathrm{See}$ id. at 355.

${ }^{72}$ See id. at 348.

${ }^{73}$ See id.
} 
but with a crime rate of $84.2 \%$ the probability is .59 . In one case, therefore, a typical person has better than even odds of not being victimized, whereas in the other case, the same person more likely than not will become a victim of a major crime.

Thus, segregation interacts with rising black poverty to concentrate poverty geographically, which in turn concentrates crime, thus creating an ecological niche characterized by a high level of violence and a high risk of victimization. The concentration of crime is brought about by just two conditions that we know to have characterized U.S. metropolitan areas during the 1970s and 1980s: high levels of racial segregation and rising rates of black poverty. ${ }^{74}$ Given the correlation between poverty and crime, the concentration of crime follows axiomatically from these structural conditions: no other outcome is possible.

The ecological niche created by racial segregation and high black poverty defines the social environment to which poor blacks must adapt. Given the barriers to black residential mobility, escape is difficult, if not impossible. How does a person adapt to a harsh environment where violence is endemic, the odds of criminal victimization are high, and the risk of death or injury substantial? The most logical individual adaptation is for one to become violent oneself. By adopting a threatening demeanor, cultivating a reputation for the use of force, and selectively backing up that reputation with actual violence, one can deter potential criminals and increase the odds of survival.

In a social world characterized by endemic, exogenously induced violence, therefore, violent behavior and an obsessive concern with respect become rational strategies for survival. Given a geographic concentration of violence, some community members are sure to adopt violent attitudes and behavior as survival strategies. As more people adopt more violent strategies for self-preservation, the average level of violence within the niche rises, leading others to adopt more violent behavior. As the average level of violence rises over time, more people adopt increasingly violent strategies to protect themselves from the growing threat of victimization, ultimately producing a self-perpetuating upward spiral of crime and violence.

Although a cycle of black violence may follow axiomatically from racial segregation and black poverty, what has made the spiral so

\footnotetext{
${ }^{74}$ See id. at 329.
} 
frightening and appalling in recent years is the concomitant availability of lethal weapons of spectacular firepower. Precisely at the moment when forces in U.S. society were interacting to maximize the conditions for violence in one segment of the population, guns became cheaper and more available than ever. The existence of a racially distinctive ecological niche of violence within a society that has chosen to permit unparalleled access to automatic weapons can only produce one outcome: the spectacle of black men killing one another in increasingly violent ways.

Thus, racial segregation is deeply implicated in the tide of violence that is sweeping black America. The transformation of the urban economy from manufacturing to services, the suburbanization of employment, the decline in the real value of welfare, and the stagnation of wages have combined over the past two decades to raise the rate of black poverty; ${ }^{75}$ but high levels of segregation confined this increased poverty to a small number of racially isolated neighborhoods clustered around the urban core. As a result, the concentration of poverty was dramatically increased within segregated black communities to create an ecological niche in which crime was prevalent and violence was a logical adaptation to the harsh conditions of daily life.

\section{ADAPTING TO THE NICHE OF VIOLENCE}

The foregoing exposition provides a theoretical explanation for the rising tide of black violence that is generally consistent with the observed facts. It explains the strong association between racial segregation and crime rates observed by Logan and Messner; ${ }^{76}$ it explains why Peterson and Krivo found that segregation was associated with killings between strangers and acquaintances but not relatives; ${ }^{77}$ and it explains why crime rates continue to rise in the black community even though they are falling for other groups. ${ }^{78}$

${ }^{75}$ See Mitchell L. Eggers \& Douglas S. Massey, A Longitudinal Analysis of Urban Poverty: Blacks in U.S. Metropolitan Areas Between 1970 and 1980, 21 Soc. ScI. RES. $175,187-94$ (1992) (analyzing changes in black poverty); Mitchell L. Eggers \& Douglas S. Massey, The Structural Determinants of Urban Poverty: A Comparison of Whites, Blacks, and Hispanics, 20 Soc. SCI. RES. 217, 220-43 (1991) (analyzing similarities and differences in structural forces generating urban poverty among whites, blacks, and Hispanics).

\footnotetext{
${ }^{76}$ See supra notes $36-41$ and accompanying text.

77 See supra notes $45-46$ and accompanying text.

${ }^{78}$ See Zucchino, supra note 1 , at A22.
} 
Even though the theory of segregation explicitly links high rates of black crime to structural arrangements in society, ultimately it is a theory of microbehavior: it makes specific predictions about how people adapt to conditions of life that have been imposed on them by virtue of being confined to an ecological niche characterized by extreme levels of violence that cannot be avoided. Building a prima facie case for a connection between segregation and crime, therefore, requires information about how people negotiate the difficult conditions of life in poor, inner-city neighborhoods.

Elijah Anderson has carried out precisely this sort of analysis. ${ }^{79}$ His ethnographic research draws upon years of participant observation within one poor black neighborhood of Philadelphia, ${ }^{80}$ a city that manifestly exhibits the structural predeterminants of concentrated poverty and violence. Not only is Philadelphia characterized by a very high rate of black poverty, ${ }^{81}$ it is also one of the metropoli$\tan$ areas Denton and I described as hypersegregated, ${ }^{82}$ due to the extreme segregation of blacks on multiple geographic dimensions, a condition that Denton has reconfirmed as of $1990 .{ }^{83}$

As a result of these two features of Philadelphia's social structure-high segregation and high black poverty-Eggers and I found a remarkably high concentration of black poverty. ${ }^{84}$ According to our calculations, the average poor black family lived in a neighborhood that was $34.7 \%$ poor in 1980 , whereas the average poor white family lived in a neighborhood that was only $13.8 \%$ poor. ${ }^{85}$ An average value of $30 \%$ suggests that many poor black families experience substantially higher rates of neighborhood poverty than whites, in some cases living in neighborhoods where more than $50 \%$ of the families are below the poverty line. ${ }^{86}$ Poor whites almost never live in such neighborhoods. ${ }^{87}$

${ }^{79}$ See generally Elijah Anderson, The Code of the Streets, ATLANTIC MONTHLy, May 1994, at 81 (examining social conditions in poor, black, inner-city communities that perpetuate violence).

${ }^{80}$ See Elijah Anderson, Streetwise: RaCe, Class and Change in aN URbaN COMMUNITY 7-54 (1990) (describing methods and setting of the case study).

${ }^{81}$ See U.S. BuREAU OF THE CENSUS, 1990 CENSUS OF Population, Social aNd Economic Characteristics, Pennsylvania 557 (U.S. Gov't Printing Office, Washington D.C.) (recognizing Philadelphia as having a $29 \%$ black poverty rate but only an $11 \%$ white poverty rate).

${ }^{82}$ See Massey \& Denton, supra note 28 , at $382,388$.

${ }^{83}$ See Denton, supra note 29 , at 56-63.

\& See Massey \& Eggers, supra note 56, at 1174-76.

${ }^{85}$ See id.

${ }^{86}$ See id.

${ }^{87}$ See Douglas S. Massey et al., Segregation, the Concentration of Poverty, and the Life 
The specific neighborhood studied by Anderson typifies the ecological niche of violence that follows from a city like Philadelphia's structural conditions: it is a place of "[m]uggings, burglaries, carjackings, and drug-related shootings, all of which may leave their victims or innocent bystanders dead." ${ }^{88}$ According to Anderson, this social environment reflects the disproportionate concentration of "street families" within it. ${ }^{89}$ People from such families "show a lack of consideration for other people and have a rather superficial sense of family and community." disorganization." ${ }^{\text {91 }}$ They "frequently have a limited understanding of priorities and consequences, and so frustrations mount over bills, food, and, at times, drink, cigarettes, and drugs." 92 In addition, "some tend toward self-destructive behavior."

Anderson links this destructive behavior to persistent poverty:

[T] he seeming intractability of their situation, caused in large part by the lack of well-paying jobs and the persistence of racial discrimination, has engendered deep-seated bitterness and anger in many of the most desperate and poorest blacks .... [T]he frustrations of persistent poverty shorten the fuse in such people-contributing to a lack of patience with anyone, child or adult, who irritates them. ${ }^{94}$

In other words, the proclivity toward violence is produced by longterm poverty. By concentrating the persistently poor in certain neighborhoods, segregation has concentrated a "street orientation," creating a social world characterized by high levels of interpersonal hostility and aggression. ${ }^{95}$

Low-income black neighborhoods also contain what Anderson calls "decent families." According to Anderson:

[D]ecent families tend to accept mainstream values more fully and attempt to instill them in their children. ... They value hard work and self-reliance and are willing to sacrifice for their children....

Chances of Individuals, 20 Soc. ScI. RES. 397, 400-01 (1991) (noting that "exposure to high levels of neighborhood poverty is alien to the experience of most whites").

${ }^{88}$ Anderson, supra note 79 , at 81 .

${ }^{89}$ See id. at 82.

${ }^{90} \mathrm{Id}$. at 83.

${ }^{91}$ Id.

92 Id.

${ }^{93}$ Id.

${ }^{94}$ Id.

${ }^{95}$ See id.

${ }^{96} I d$. at 82. 
Extremely aware of the problematic and often dangerous environment in which they reside, decent parents tend to be strict in their child-rearing practices, encouraging children to respect authority and walk a straight moral line. ${ }^{97}$

Even if children come from decent families, however, they must adapt to a social world that is disproportionately influenced by the culture, values, and behavior of the street. As Anderson argues, "[s]imply living in such an environment places young people at special risk of falling victim to aggressive behavior. . . Above all, this environment means that even youngsters whose home lives reflect mainstream values ... must be able to handle themselves in a street-oriented environment." ${ }^{98}$

Thus, the fundamental need to adapt to conditions of endemic violence that are structurally imposed and inescapable has led to the evolution within poor, inner-city black neighborhoods of a "code of the streets" that encourages and promotes the use of force, even among "decent" families. According to Anderson:

[This code] amounts to a set of informal rules governing interpersonal public behavior, including violence. The rules prescribe both a proper comportment and a proper way to respond if challenged. They regulate the use of violence and so allow those who are inclined to aggression to precipitate violent encounters in an approved way. The rules have been established and are enforced mainly by the street-oriented, but on the streets the distinction between street and decent is often irrelevant; everybody knows that if the rules are violated, there are penalties. Knowledge of the code is thus largely defensive; it is literally necessary for operating in public. Therefore, even though families with a decency orientation are usually opposed to the values of the code, they often reluctantly encourage their children's familiarity with it to enable them to negotiate the inner-city environment. ${ }^{99}$

This passage provides a succinct description of the self-perpetuation of violence through rational, microlevel decisions taken by families and individuals who are forced to confront a hostile social environment. Asking residents of poor, racially isolated neighborhoods to "choose" a less violent path or to say "no" to the temptation of the streets is absurd, given the threatening character of the niche in which they live. To survive on the streets of segregated,

${ }^{97}$ Id. at $82-83$.

${ }^{98}$ Id. at 81-82.

${ }^{99}$ Id. at 82 (emphasis added). 
inner-city America, one must learn, and to a significant extent internalize, the code of violence. In this way, violent behavior is passed from person to person and parents to children in a selffeeding, escalating fashion, precisely in the manner predicted by the theory of residential segregation.

A primary concern of those invested in the code of the streets is the maintenance of "respect," which is "loosely defined as being treated 'right,' or granted the deference one deserves." 100 Within a hostile and violent social world, the maintenance of respect is much more than a vain concern with appearances; it is a critical social resource that promotes physical security and survival, because "[w]ith the right amount of respect [a person] can avoid 'being bothered' in public."101

In essence, what the code of the streets provides is a framework for negotiating respect. In a niche of violence, respect can only be built and maintained through the strategic use of force. Anderson explains that, beginning in childhood, individuals in these communities are socialized to fight in order to earn respect. ${ }^{102} \mathrm{He}$ writes, "the violent resolution of disputes, the hitting and cursing, gains social reinforcement. [Children] in effect [are] initiated into a system that is really a way of campaigning for respect. . . . Many parents actually impose sanctions if a child is not sufficiently aggressive." 103

Within an ecological niche characterized by high rates of crime and violence, therefore, respect is a scarce but important social resource that actors attempt to cultivate in order to lower the risk of criminal victimization. The cultivation of respect through the strategic use of violence represents a logical, instrumental strategy pursued by rational individuals as a means of adapting to the harsh conditions of daily life created by structural arrangements in American society that are beyond individual control.

The inhabitants of poor, inner-city neighborhoods not only pursue individual strategies to reduce their risk of victimization; they also act collectively. Perhaps the most common collective response to the niche of violence is the formation of gangs, whose role and function in low income neighborhoods have been studied in detail by Martín Sánchez Jankowski. ${ }^{104}$ In essence, gangs

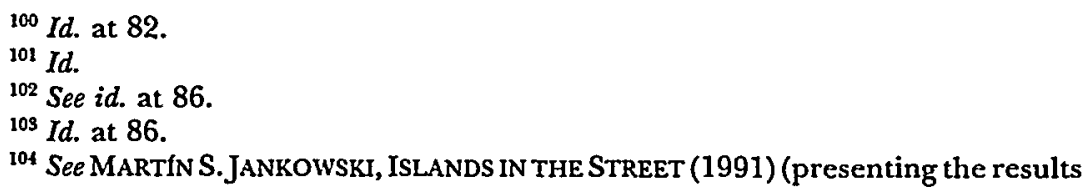


collectivize the code of the streets, which he calls "defiant individualism," through an explicit organizational structure that controls and regulates the use of force. ${ }^{105}$

According to Jankowski, individuals join gangs for a variety of reasons, but one central motivation is self-protection: "Individuals ... join gangs because they believe the gang can provide them with personal protection from the predatory elements active in lowincome neighborhoods." 106 People, quite rationally, "are either tired of being on the alert or want to reduce the probability of danger to a level that allows them to devote more time to their effort to secure more money." 107

Joining a gang thus provides a way of substantially increasing one's "respect" while minimizing personal effort and risk. Membership in a gang provides a deterrent against attacks and victimization, because an attack on one gang member constitutes an attack on the group and can trigger a violent response not simply from the victim but from all members of the gang. ${ }^{108}$ Thus, whereas "respect" is a form of human capital that individuals must laboriously cultivate through their actions and behavior, gang membership is a form of social capital that may be accessed simply by joining.

Gangs also provide benefits to the neighborhood as a whole. Although gangs do not eliminate violence, they at least control and regulate it and generally deflect it away from territories and groups they cover. ${ }^{109}$ Residents of the neighborhoods studied by Jankowski

emphasized that gangs are more able to deter crime in their community than the police because gang members are distributed throughout the community and are able to identify strangers ....

... [T] They are not restrained from taking immediate action against anyone considered a community threat.... Unlike the police, the gang can administer physical injury without regard to laws designed to restrain such action. ${ }^{110}$

of a 10-year research project on gangs).

${ }^{105} \mathrm{Id}$. at 23-28 (defining the term and its component concepts).

${ }^{106} \mathrm{Id}$. at 44 .

${ }^{107}$ Id.

${ }^{108}$ See id. at 45 (giving accounts of gang members' reasons for joining gangs).

${ }^{109}$ See id. at 183 (noting that "[p]robably the most important service that gangs can provide is protection").

${ }^{110}$ Id. at 184. 
Gangs also provide special protection for the weakest members of the community: children and the elderly. According to Jankowski:

In 84 percent (31) of the [thirty-seven] cases that I studied, gangs provided at least escort service for anyone in the community who asked for it....

In addition to trying to assume responsibility for protecting residents from being accosted and/or robbed, all but three of the gangs that I studied also tried to protect them from other social predators, like loan sharks, unethical landlords, and/or store owners who overcharged for their products. ${ }^{11}$

Despite these benefits to individuals and communities, gangs carry costs because they inevitably become engines of violence themselves. ${ }^{112}$ In order to ensure their own survival as organizations, gangs must acquire capital, which moves them into illegal activities, notably the marketing and distribution of illegal drugs. ${ }^{113}$ In addition, the survival of a gang requires the frequent use of force against rival gangs who seek to enter their market areas or zones of social influence. ${ }^{114}$ They must also apply force whenever the well-being or reputation of a member is threatened. ${ }^{115}$ Rather than a spiral of individual-level violence, therefore, gangs more often produce a spiral of collective violence between competing organizations. ${ }^{116}$

Thus, two detailed ethnographic studies of poor, inner-city areas $^{117}$ yield descriptions of individual and collective behavior that are consistent with the line of theoretical reasoning developed here. The ecological niche of violence promotes and perpetuates high levels of violence among blacks in two ways: by encouraging the formation of criminal gangs at the collective level and by fostering an obsessive concern for respect at the individual level. The wave of crime in urban black America is not simply a product

III Id. at 185-86.

${ }^{112}$ See id. at 137-77 (outlining the varieties and causes of gang-related violence).

${ }^{113}$ See id. at 120 (noting that the "biggest money-maker and the one product nearly every gang tries to market is illegal drugs").

11 See id. at 161-64 (discussing intergang violence).

${ }^{115} \mathrm{See} i d$. at 162 (describing how some violence arises when "a leader of a particular gang feels that he has lost some of his status or authority").

${ }^{116}$ See id. at 164 (noting that "[f]ear of being attacked by a rival gang stimulates a 'first strike' mentality").

${ }^{117}$ See generally id.; Anderson, supra note 79. 
of individual moral failings; it is an inevitable outgrowth of social conditions created by the coincidence of racial segregation and high rates of black poverty.

\section{Violence AND THE POLITICS OF SEgRegation}

If segregation is a fundamental factor behind the crime wave now sweeping American inner cities, a logical question is why so little has been done to desegregate U.S. urban areas. In the years since the passage of the 1968 Fair Housing Act, levels of black-white segregation have hardly changed, particularly in metropolitan areas with large black populations. ${ }^{118}$ In thirty metropolitan areas with the largest black populations, for example, on a scale of zero to one hundred, the level of black isolation stood at sixty-nine in 1970 and sixty-seven in $1990 .{ }^{119}$

A major reason for the lack of change is that most Americans, particularly whites, perceive themselves as benefitting from the social arrangements that produce racial segregation. If poverty rates are higher for blacks and if crime is associated with poverty, then, by isolating blacks in segregated neighborhoods, the rest of society insulates itself from the crime and other social problems that stem from the higher rate of black poverty. ${ }^{120}$

The benefits accruing to the rest of society from racial exclusion are illustrated in Table II, which examines what happens to the neighborhood environment experienced by the average poor white person as a result of racial segregation. As before, I began with an initial black poverty rate of $20 \%$, compared to $10 \%$ for whites, and then raised the black rate to $30 \%$ while keeping the white rate constant. ${ }^{121}$ I sought to show what happens to the neighborhood of poor whites when a shift in black poverty rates occurs under conditions of no and high class segregation, and no and complete racial segregation. ${ }^{122}$

${ }^{118}$ See Reynolds Farley \& William H. Frey, Changes in the Segregation of Whites from Blacks During the 1980s: Small Steps Toward a More Integrated Society, 59 AM. Soc. REV. $23,30-38$ (1994) (discussing the data generated by various studies on segregation).

${ }^{119}$ See Massey, supra note 29.

${ }^{120}$ See Massey, supra note 48 , at 353 (explaining the benefits of segregation for whites).

${ }^{121}$ See id. at 331-50 (setting forth parameters and results of the simulation); see also text accompanying note 48 .

${ }^{122}$ See Massey, supra note 48, at 331 (setting forth the goals of the simulation). 


\section{TABLE II ${ }^{123}$}

EFFECT OF RISING BLACK-WHITE SEgREgation AND RISING RATES

OF BLACK POVERTY ON THE GEOGRAPHIC CONCENTRATION OF POVERTY AND CRIME IN WHITE NEIGHBORHOODS

For Typical Poor White Person:

\begin{tabular}{ll} 
Neigh- & Neigh- \\
borhood & borhood \\
Poverty & Crime \\
Rate & Rate \\
\hline
\end{tabular}

WITHOUT CLASS SEGREGATION

Racially Integrated City

Black Poverty Rate 20\%

$12.5 \%$

$47.9 \%$

Black Poverty Rate 30\%

15.0

49.9

Racially Segregated City

Black Poverty Rate 20\%

10.0

46.5

Black Poverty Rate $30 \%$

10.0

46.5

WITH CLASS SEGREGATION

Racially Integrated City

Black Poverty Rate 20\%

25.0

57.8

Black Poverty Rate 30\%

30.0

61.8

Racially Segregated City

Black Poverty Rate 20\%

20.0

54.4

Black Poverty Rate $30 \%$

20.0

54.4

Assuming class segregation gives the most realistic assessment of what will happen to whites as a result of increasing black poverty and imposing racial segregation. In a city that is segregated by class but not by race, the average poor white person will inhabit a neighborhood where $25 \%$ of the residents are poor. Increasing the black poverty rate to $30 \%$ while maintaining other conditions produces a relatively high neighborhood poverty rate of $30 \%$.

Imposing racial segregation, however, yields substantially lower levels of neighborhood poverty for poor whites. ${ }^{124}$ Isolating blacks II).

${ }^{123}$ See Massey, supra note 48, at 338-39, 355 (providing source of data for Table

${ }^{124}$ See id. at 336 (noting that the "imposition of racial segregation on a residential 
within their own neighborhoods means that only blacks experience the problems stemming from their elevated income deprivation: whites end up with lower rates of neighborhood poverty. ${ }^{125}$ In the simulation, the rate of poverty in the neighborhood of the average poor white person drops to $20 \%$ when racial segregation is imposed, a situation that does not change even if the black poverty rate is increased to $30 \%$ because, under conditions of racial segregation, all of the increased poverty is, by definition, confined to black neighborhoods. ${ }^{126}$

As a result of the lower rate of neighborhood poverty, therefore, poor whites experience significantly lower crime rates by imposing racial segregation, because crime follows poverty. ${ }^{127}$ Rather than a neighborhood crime rate of $61.8 \%$ (in a city with a black poverty rate of $30 \%$ and racial integration), whites experience a neighborhood crime rate that is roughly $10 \%$ lower at $54.4 \%$ (in a racially segregated city with the same poverty rate). By segregating blacks and their social problems, in other words, poor whites derive a benefit in the form of lower rates of neighborhood crime. Even though society as a whole may be damaged by this arrangement, and long-term costs may be greater, whites generally perceive themselves to be better off as a result of segregation. ${ }^{128}$

In fact, this simulation understates the degree to which whites perceive themselves to be better off. In reality, whites do not compare their current crime rate with the one that would occur if there were no racial segregation, because they do not have an opportunity to observe the counterfactual situation of racial integration. ${ }^{129}$ Rather, they compare their neighborhood crime rate with the one they currently observe in segregated black communities. ${ }^{130}$

structure that is also segregated by class works to the detriment of poor blacks and to the benefit of poor whites").

${ }^{125}$ See id. (describing how the simulation shows that "the size of the black-white disparity [in neighborhood poverty rates] increases as racial segregation rises").

${ }^{126}$ See id. at 341.

${ }^{127}$ See id. at 347 (noting that "[l]oss of income and rising poverty are also associated with increasing rates of crime and violence").

${ }^{128}$ See id. at 353 (contending that "Whites benefit from segregation because it isolates higher rates of black poverty within black neighborhoods").

${ }^{129}$ See id. (noting that "[s]egregation heightens and reinforces negative racial stereotypes by concentrating people who fit those stereotypes in a small number of highly visible minority neighborhoods").

${ }^{130}$ See id. (noting that "higher concentrations of black poverty then reinforce the connection, in whites' minds, between black race and behaviors associated with poverty"). 
Instead of a crime rate of $61.8 \%$ in the counterfactual case of a racially integrated city, whites actually see a crime rate of $84.2 \%$ in segregated black communities, a differential of almost $50 \%{ }^{131}$ In contemplating desegregation, therefore, whites imagine themselves being exposed to the high crime rates they observe in the ghetto, which are themselves a product of segregation. ${ }^{132}$

Thus, by creating a niche of violence and establishing the social conditions for a self-perpetuating cycle of crime, segregation paradoxically raises the perceived costs of desegregation for whites while imposing ever higher penalties on blacks. In short, segregation simultaneously victimizes blacks while giving whites greater incentive to maintain the residential status quo, leading to a vicious cycle whereby segregation promotes poverty among blacks, leading to behavior that hardens white prejudice and discrimination, which in turn promotes further socioeconomic damage to the black community, which leads to continued segregation. ${ }^{133}$

In addition to lower crime rates, racial segregation provides another benefit to whites in the form of lower taxes. Because blacks have a higher poverty rate than other groups in American society, their inclusion within the same taxing district necessarily generates higher costs for the rest of society in the form of greater expenses for health, education, welfare, and criminal justice. Therefore, to the extent that it isolates poor blacks within separate jurisdictions, segregation lowers the tax burden for whites.

This outcome, however, requires that residential segregation not only occur at the neighborhood level, but also at the administrative level. Neighborhood-level segregation may confine many blacks and their social problems to certain residential areas, but if whites and blacks live in the same municipality, whites still have to shoulder the costs of black poverty. If, however, blacks are segregated across municipal as well as neighborhood boundaries, not only can whites minimize their exposure to crime and other social problems, but to a large extent, they can also avoid paying the costs.

${ }^{131}$ See id. at 347 (reporting crime rates as high as "84 per thousand under conditions of maximum segregation").

132 See id. at 353 (describing how "[t]he persistence of segregation, in turn, worsens the concentration of poverty, putting additional downward pressure on black socioeconomic status, making further segregation and discrimination more likely").

${ }^{193}$ See George C. Galster \& W. Mark Keeney, Race, Residence, Discrimination, and Economic Opportunity: Modeling the Nexus of Urban Racial Phenomena, 24 URB. AFF. Q. 87, 105-06 (1988) (setting forth a nonlinear "feedback loop" model to explain phenomena related to segregation). 
Historically, of course, blacks were isolated from whites across state and county boundaries. Prior to 1900 , blacks largely resided in rural counties of the South, and most whites were neither exposed to problems arising from black poverty nor affected by the costs. Within the South, whites were protected from the deleterious consequences of black poverty by the Jim Crow system. With massive migration from the rural South to cities of both the North and South, however, this regional segregation ended, and whites and blacks came to occupy common municipalities around the United States. ${ }^{134}$

As blacks moved into cities, successively higher levels of residential segregation were imposed to keep racial mixing within neighborhoods to a minimum. ${ }^{135}$ Until 1950 this segregation occurred primarily at the level of blocks or census tracts. ${ }^{136}$ Through the Second World War, urban blacks and whites lived under common municipal governments, forcing whites to share the costs of black social problems. ${ }^{137}$ After 1950, however, segregation increasingly occurred not only at the neighborhood level, but also at the municipal level. ${ }^{138}$

According to Zoltan Hajnal and me, the degree of segregation between blacks and whites across city boundaries steadily rose after $1950 .^{139}$ Using an index of segregation that varies from 0 to 100 (the index of dissimilarity), we found that the level of black-white segregation increased from 35 to 49 from 1950 to 1980, an upward shift of $40 \% .^{140}$ The degree of black isolation within municipalities increased correspondingly. ${ }^{141}$

During the postwar period, significant municipal-level segregation emerged throughout the urban hierarchy-in small and large cities located at the urban core, in suburbs, as well as in non-

${ }^{134}$ See REyNOLDS FARLEY \& WALTER R. ALLEN, THE COLOR LINE AND THE QUALITY OF LIFE IN AMERICA 103-19 (1987); Douglas S. Massey \& Zoltan L. Hajnal, The Changing Geographic Structure of Black-White Segregation in the United States, 76 Soc. SCI. Q. (forthcoming Sept. 1995).

${ }^{135}$ See STANLEY Lieberson, A PIECE Of THE PIE: BLACK AND WhITE IMMigRanTs SINCE 1880, at 291 (1980) (speculating that "increasing black isolation occurred simply because whites in each city were attempting to maintain the degree of isolation from blacks that existed before the new flows from the South started").

${ }^{136}$ See Massey \& Hajnal, supra note 134.

${ }^{137}$ See id.

${ }^{138}$ See id.

139 See id.

${ }^{140}$ See id.

${ }^{141}$ See id. 
metropolitan areas. Among cities with 100,000 or more inhabitants, for example, none were predominantly black in $1950,{ }^{142}$ but by 1990 fourteen were at least half black, including Atlanta, Baltimore, Detroit, Gary, Newark, New Orleans, and Washington. ${ }^{143}$ Among cities of 25,000 or more inhabitants, only two municipalities were more than half-black in 1950 (both in the South), ${ }^{144}$ but by 1990 the number had increased to forty. ${ }^{145}$ Many observers have noted the recent emergence of black suburbs, ${ }^{146}$ and at least one observer has documented the growth of black cities in formerly nonmetropolitan areas of the South. ${ }^{147}$

The segregation of blacks within all-black municipalities adds a new layer of isolation to that already achieved by segregation at the neighborhood level: fiscal isolation. Given segregation at the municipal level, whites not only benefit by limiting their exposure to crime and the other social problems arising from black poverty, but they escape the financial burdens as well.

In summary, racial segregation persists in the United States because whites benefit from it. In undermining the socioeconomic status and well-being of African-Americans and deepening their social problems, segregation simultaneously increases the incentives for whites to maintain the residential status quo. As social conditions in the nation's ghettos deteriorate, policies to promote desegregation become less popular politically, thereby making a resolution of the nation's crime problem that much more remote.

142 See U.S. DEP'T OF COMMERCE, COUNTY AND CITY DATA BOOK: 1952, at 442-505 (1953) [hereinafter COUNTY AND CITY DATA BOOK].

145 See U.S. DEP'T OF COMMERCE, STATISTICAL ABSTRACT OF THE U.S.: 1992, at 3437 (112th ed. 1992).

14 See COUNTY AND CITY DATA BooK, supra note 142, at 442, 466 .

${ }^{145}$ See Massey \& Hajnal, supra note 134.

${ }^{146}$ See generally Larry Long \& Diana DeAre, The Suburbanization of Blacks, AM. DEMOGRAPHICS, Sept. 1981, at 16 (discussing the significant increase in blacks moving to the suburbs); William P. O'Hare \& William H. Frey, Booming, Suburban, and Black, Am. Demographics, Sept. 1992, at 30 (same); Mark Schneider \& Thomas Phelan, Black Suburbanization in the 1980s, 30 DEMOGRAPHY 269 (1993) (examining black suburban residential patterns); Linda B. Stearns \& John R. Logan, The Racial Structuring of the Housing Market and Segregation in Urban Areas, 65 SOC. FORCES 28 (1986) (analyzing the factors that affect black suburbanization).

${ }^{147}$ See Charles S. Aiken, A New Type of Black Ghetto in the Plantation South, 80 ANNALS AM. GEOGRAPHERS 223, 223 (1990) (discussing the "increase in segregation among the municipalities of the Yazoo Delta," a nonmetropolitan area of Mississippi). 


\section{Alternative SCENARIOS For the FUtURE OF URBAN AMERICA}

In this Article, I have developed a line of theoretical reasoning that connects the rising tide of crime in inner-city black neighborhoods to basic structural features of American society, as opposed to the individual failings of African-Americans. I showed how two features of metropolitan social structure-high rates of black poverty and high levels of black segregation-interact to produce an ecological niche within which poverty is concentrated and crime is prevalent.

African-Americans who are forced to inhabit this structurally produced niche must adapt to a violent social world where the chance of criminal victimization is great. According to ethnographic data from high-crime areas, adaptive responses to this environment have occurred at both the individual and collective level. At the individual level, rational actors attempt to build and cultivate "respect" through the strategic and frequent use of violence. A willingness to use violence provides a deterrent against predators inhabiting the niche, thereby lowering the odds of victimization. As such, it constitutes a valuable form of human capital in the ghetto. As more people adopt more violent strategies for survival, however, the average level of violence rises, causing even more people to adopt even higher levels of violence, leading to a self-perpetuating cycle of violence.

At the collective level, people turn to gangs to protect themselves from the ongoing threat of violence. Membership in a gang gives an actor access to the deterrence of violence without having to build and cultivate an individual reputation for violence. A person simply taps into the "respect" accorded the gang through its reputation for the use of violence and mutual defense. Gang membership provides a valuable form of social capital that can significantly lower the odds of victimization within the niche of violence. Once again, however, gangs create new opportunities and motivations for the expression of violence, and in the long run produce better-organized violence on a larger scale, even as they protect the interests of certain individuals.

Thus, the present cycle of urban violence does not primarily stem from individual failings, but from basic structural features of urban society that create a niche of violence to which black Americans must adapt. Sadly, in promoting high levels of violence among blacks, segregation simultaneously gives whites a strong incentive to maintain the status quo and to perpetuate the ghetto as 
a basic feature of American life. As a result, segregation has grown more intense in recent years as it has moved beyond the neighborhood level to occur increasingly at the municipal level. At present, blacks and whites are not just socially isolated; they are fiscally isolated as well. Through municipal-level segregation, blacks are forced to bear a larger share of the costs of their own victimization, while whites escape the high costs of black poverty, at least in the short term.

Elsewhere, others and I have outlined the federal policy initiatives that would need to be undertaken to end the legacy of American Apartheid. ${ }^{148}$ Despite the fact that most of these policies were implemented by Secretary of Housing and Urban Dexelopment Henry Cisneros during the first two years of the Clinton administration, ${ }^{149}$ it is difficult to be optimistic about the future welfare of either cities or black America, given the understanding of the origins and nature of black crime developed above.

In the current political climate, which emphasizes a reduced role for government, limited discretionary spending at the federal level, and a profound reluctance to embrace race-specific remedies, the chances of a major new desegregation initiative seem remote indeed. Yet unless forceful action is undertaken soon to desegregate urban America, the cycle of black, urban violence can be expected to continue. As the cycle of violence continues, political support for a policy of desegregation will wither and become even more remote, leading to the perpetuation of the multiple problems created by the coincidence of segregation and black poverty.

\section{CONCLUSION}

At present, the United States appears to be locked into a set of institutional arrangements that will only exacerbate racial inequalities, perpetuate urban violence, deepen the socioeconomic problems of African-Americans, and erode the status and well-being of American cities. As major cities in general, and urban black

${ }^{148}$ See MASSEY \& DENTON, supra note 27, at $229-33$ (detailing federal policy initiatives necessary to ending racial segregation); YINGER, supra note 30 (advocating eradicating market and government discrimination, the offsetting of past discrimination, making integration a real choice, and supporting personal responsibility).

${ }^{149}$ See, e.g., J. Linn Allen, Open-Minded; Fair Housing Advocate Aurie Pennick Says Integration Is Still the Key to a Better World, CHI. TRIB., Dec. 6, 1994, at C1 (noting a HUD grant to help families in public housing move to middle-class areas); Ruth Rendon, Many Schools Resegregated, NAACP's Chavis Says, Hous. CHRON., Feb. 26, 1994, at A30 (noting Cisneros's efforts in integrating a housing project). 
communities in particular, continue to deteriorate fiscally, socially, and economically, the socioeconomic health of the nation will also erode. Despite the efforts of white Americans to escape urban problems through segregation, they will inevitably end up paying the costs-directly in the form of higher expenses for insurance, health care, criminal justice, security, and education, and indirectly in the form of reduced competitiveness in world markets, diminished quality of life, and a retreat from American democratic ideals. 